his book indicate that piecemeal policymaking may be misguided in areas of science where developments are rapid, and vulnerable to the vagaries of politics. The use-versusderivation approach vaunted by the NIH and AAAS was hoist by its own petard. Already schizophrenic, in the hands of President Bush it became even more bizarre when he decreed that only existing embryonic stem-cell lines could be researched with public monies. Not all of these cell lines have been published, nor have they been adequately characterized. Moreover, they were created using mouse feeder cells which, according to guidelines of the Food and Drug Administration, would render cells derived from them xenografts, not purely human.

Because of the huge potential benefits of research on human embryonic stem cells and because so little is known about them, a sensible policy should be wide, not narrow, in its scope. Of course, the NIH and AAAS (and arguably Bush) strained every nerve to ensure that public money for embryonic stem-cell research was made available. But Green's criteria for sound policy-making were not satisfactorily met in the process. Green, perhaps, 'went native' in Washington, despite himself.

Serious readers of science, philosophy, law and government who are interested in medical research cannot fail to enjoy The Human Embryo Research Debates. It should be required reading for students across these disciplines, not to mention for those on the right of so-called 'abortion politics' - if they care about the arguments, that is.

Justine Burley is at Exeter College, University of Oxford, Oxford OX1 3DP, UK. Alan Colman is at PPL Therapeutics, Roslin Institute, Edinburgh EH25 9PP, UK.

\section{More on the embryo debate}

The Human Embryonic Stem Cell Debate: Science, Ethics, and Public Policy

edited by Suzanne Holland, Karen Lebacqz

\& Laurie Zoloth

Cambridge University Press, $£ 90, \$ 130$

\section{What if Mendel had studied sheep?}

\section{Genetic Prehistory in Selective Breeding: A Prelude to Mendel by Roger J. Wood \& Vítězslav Orel}

Oxford University Press: 2001. 342 pp.

$\mathfrak{E 4 9 . 5 0 , \$ 8 5}$

\section{William G. Hill}

Successful improvement of crops and livestock was carried out long before Mendel elucidated the principles of inheritance, and the effectiveness of artificial selection was a major contributor to Darwin's theory of evolution by natural selection. Quite simply,

as offspring resemble their parents, selective breeding usually provides results. Indeed, simple selection of the best performers is still the main component of most animal breeding programmes for major traits such as growth rate. But we can now use Mendel's laws to explain why it works and is an efficient practice.

In Genetic Prehistory in Selective Breeding, Roger Wood, of the University of Manchester, and Vítězslav Orel, emeritus head of the Mendelianum in Brno, aim to set the scene for Mendel's work, particularly in the context of ideas and practice in animal breeding in central Europe. The superior fine wool of the Spanish merino sheep was recognized in the textile industry; but, in an old version of the nature-nurture debate, an important question was the extent to which its quality would be retained in different environments and in successive crosses to local breeds. Among those interested was C. F. Napp, who was abbot of the monastery at Brno when Mendel entered it in 1843 and throughout the time of the latter's famous work. Napp participated in the discussions of the local sheep-breeders' society, was interested in the scientific basis of improvement and was presumably a stimulus to Mendel.

In the later part of the eighteenth century, Robert Bakewell in England had demonstrated the effectiveness of selection - aided by inbreeding - to fix qualities, with great success and to widespread acclaim. His influence was substantial and many interested breeders, including some from central Europe, visited him. Bakewell, however, had

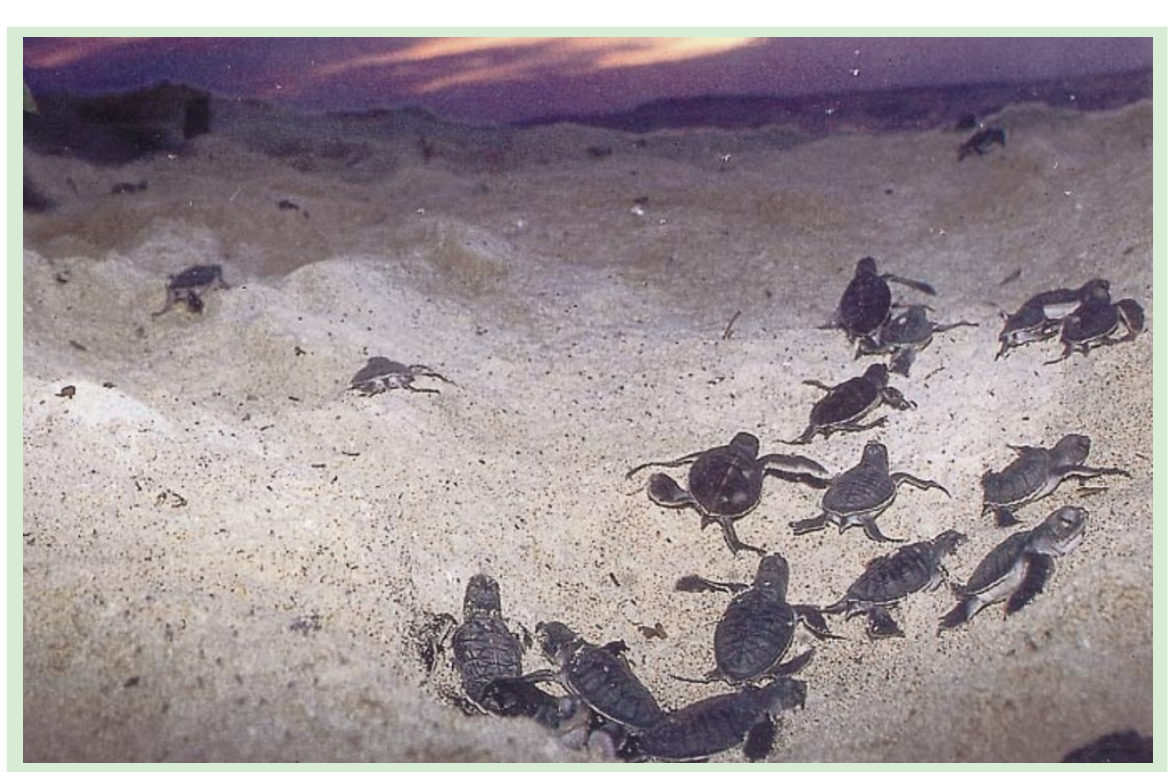

\title{
A trip to the sea
}

Dawn, and a clutch of hatchling green sea turtles (Chelonia mydas) emerge from their nest on a beach on Sipadan Island, Borneo, to make for the relative safety of the sea. Turtles, Tortoises \& Terrapins: Survivors in Armor improved meat production in sheep and so it was not certain that his methods were relevant to improving wool quality and yield. Wood and Orel's chapters on Bakewell's ideas and work are, in themselves, a fascinating story, although better known than that of the work of breeders in mainland Europe.

While the problems of sheep, and specifically wool, improvement were presumably a stimulus to Mendel, both his and his abbot's interests were wider. Napp, for example, was also president of the area's Pomological and Oenological Society. Perhaps more significantly for the advancement of science, Mendel conducted his crossing experiments on traits with discrete classes - the tall and dwarf peas had a non-overlapping distribution. He would almost certainly have got nowhere studying a trait such as wool diameter, which has a continuous distribution and no clearly segregating classes in a cross.

Although I do not find Wood and Orel's implicit thesis of the important influence of sheep-breeding on Mendel's work wholly convincing, it is nevertheless both an interesting and a stimulating study. They have undertaken an impressive amount of research in the archives on sheep-breeding in Europe in the eighteenth and nineteenth centuries, and presented their findings and conclusions clearly and logically. I learnt a lot from the book.

William G. Hill is at the Institute of Cell, Animal and Population Biology, University of Edinburgh, West Mains Road, Edinburgh EH9 3JT, UK.

by Ronald Orenstein (Firefly Books, \$45) gives a comprehensive coverage of the many other species of these shelled animals - their evolution, life history and conservation. 